\title{
Teologija i ideja sveučilišnog obrazovanja
}

\author{
Šimo Šokčević*
}

\begin{abstract}
Sažetak
Članak reflektira krizu suvremenoga obrazovanja, te pokušava ponuditi smjernice za njezino prevladavanje. U prvom dijelu analizira se bit obrazovanja gdje zapažamo da se u kontekstu suvremenih tendencija ne može govoriti o obrazovanju, nego o poluobrazovanju. Poluobrazovanje je partikularno u svojem pristupu, bez cjeline teorijskog i praktičnog znanja koja čini bit obrazovanja. Nasuprot tomu, o važnosti pristupa cjelini govorio je John Henry Newman, čija je vizija obrazovanja središnja tema ovoga rada. U sklopu njegove ideje obrazovanja ključnu ulogu ima teologija kao »forma slobodnoga znanja«, kojoj posvećujemo drugi dio ovoga članka. U tom dijelu istražujemo uzroke marginalizacije teologije na sveučilištu te zaključujemo kako upravo u diskreditiranju teologije treba tražiti uzroke suvremene krize obrazovanja.

Ključne riječi: obrazovanje, sveučilište, John Henry Newman, teologija, »krug znanja
\end{abstract}

\section{Uvod}

Prema kritičarima suvremene ideje obrazovanja, danas više nemamo obrazovanje u klasičnom smislu i ono je zamijenjeno nazivom »izobrazba «. ${ }^{1}$ Obrazovanje se tako poima kao atavizam prošlosti, antički i humanistički ideal koji se prvotno odnosio na program čovjekovog samoobrazovanja i oblikovanja, razvitak tijela, duha i duše da bi čovjek mogao biti samosvjesni sudionik unutar zajednice i kulture. To je bio svojevrstan put čovjeka iz »barbarstva u civilizaciju, iz nezrelosti u autonomiju. $\ll^{2}$

* Doc. dr. sc. Šimo Šokčević. Katolički bogoslovni fakultet u Đakovu, Petra Preradovića 17, p.p. 54., 31400 Đakovo, Hrvatska. E-pošta: simo.sokcevic@djkbf.hr

1 Usp. P. Bieri, Wie wäre es gebildet zu sein? Festrede, gehalten an der Pädagogischen Hochschule Bern am 4. November 2005.; K. P. Liessmann, Teorija neobrazovanosti: Zablude društva znanja, Zagreb, 2008.

2 Tako bi i današnje moderne znanosti trebale biti sredstva za postizanje slobode i samospoznaje, jer ljudski duh »hoće sebe bolje spoznati, a sva znanost i tehnika trebaju čovjeka učiniti slobodnijim u njegovu djelovanju«. K. P. Liessmann, Posljednja zadaća našeg opstanka. O obrazovanju i njegovu deformiranju u razdoblju znanja, u: D. Barbarić (ur.), Čemu obrazovanje. Razmatranja o budućnosti sveučilišta, Zagreb, 2011, str. 108 (107-116). Autor se referira na djelo: P. Bieri, 
Razlika između obrazovanja i izobrazbe je u tome što je obrazovanje nešto što »ljudi čine sa sobom i za sebe: obrazuje se samoga sebe«, dok izobrazbu prolazimo s ciljem »da bi nešto mogli« i izobrazbu nam pružaju drugi. ${ }^{3}$ Tu razliku svojevremeno je imao na umu i Friedrich Nietzsche u svojem predavanju iz 1872. godine naslovljenom $O$ budućnosti naših obrazovnih ustanova. Nietzsche ističe da postoje »ustanove obrazovanja « $\mathrm{i} »$ ustanove životne nužde«. On ne prezire ustanove životne nužde, nego samo želi napraviti jasnu distinkciju između jednih i drugih. Za njega su ustanove životne nužde one u kojima se »uči kako treba računati, gdje se ovladava jezikom saobraćanja, gdje se ozbiljno uzima geografija i gdje se oboružava začudnim spoznajama prirodne znanosti ${ }^{4}{ }^{4}$ Nietzsche istinski poštuje takva mjesta u kojima se stavlja naglasak na glagole poput »učiti«, »ovladavati«, »uzimati ozbiljno«, »oboružavati se « i sl. Međutim, takve ustanove nisu obrazovne, nego su one mjesta gdje se provodi »izobrazba, svojevrstan trening za postizanje korisnih kompetencija . $^{5} \mathrm{~S}$ druge strane, ustanove obrazovanja su mjesta koja nisu "prožeta oskudnostima i potrebitostima, to su mjesta slobode zato što su oni koji tu poučavaju slobodni od prinude na korisnost«. Jednom riječju, to su »mjesta dokolice«. Time je, prema Konradu Paulu Liessmanu, Nietzsche školi vratio njezin izvorni smisao. ${ }^{6}$

Dakle, iako nitko nema ništa protiv ustanova životne nužde koje provode izobrazbu, problem je to što su te ustanove u suvremenoj perspektivi ostale jedine, tj. što su istisnule ustanove obrazovanja ili su se ustanove obrazovanja transformirale u ustanove životne nužde (sukladno »duhu vremena«), te izgubile svoju bit. Danas se zbog toga suočavamo s ozbiljnom krizom sveučilišnoga obrazovanja koja je složena, te stoga ovim radom želimo ukazati na neke od neuralgičnih točaka te krize te ponuditi smjernice za njezino što uspješnije prevladavanje. Te neuralgične točke koje dovode do krize su: nedostatak normativne ideje obrazovanja, kvaliteta obrazovanja determinirana tržištem rada te umanjivanje značaja humanističkih znanosti, napose teologije, unutar akademskoga diskursa. Stoga, nam je cilj ukazati na ulogu teologije kao »forme slobodnoga znanja«, kao one koja transcendira i prožima druge znanosti. Da bi taj cilj bio i ostvaren, polazimo od analize ideje obrazovanja tematizirane u mislima nekih od glavnih teoretičara filozofije obrazovanja, te kompariramo njihove ideje s idejom sveučilišnoga obrazovanja Johna Henryja Newmana koju donosi u svojem djelu The Idea of a University. Tom metodom dolazimo do uzroka, ali i potencijalnih putokaza za prevladavanje spomenute višeslojne krize obrazovanja s kojom se danas suočavamo.

Wie wäre es gebildet zu sein? Festrede, gehalten an der Pädagogischen Hochschule Bern am 4. November 2005.

3 Usp. K. P. Liessmann, Posljednja zadaća našeg opstanka. O obrazovanju i njegovu deformiranju u razdoblju znanja, str. 108.

4 Isto str. 111. Autor se referira na djelo: F. Nietzsche, Sämtliche Werke, u: G. Colli, M. Montinari (ur.), Kritische Studienausgabe, München, 1980, br. 1, str. 716.

5 Isto.

6 Isto str. 111-112. 


\section{Sveučilište bez ideje?}

»Uvijek je lako razmišljati glavom svojega doba, teško je razmišljati vlastitom. $\ll^{7}$

\subsection{Bit (polu)obrazovanja}

Da bismo mogli shvatiti važnost obrazovnih ustanova i što se gubi iz vida transformacijom o kojoj Nietzsche govori, važno je da prije svega shvatimo bit obrazovanja. Činjenica je da svemu što ljudi moraju i mogu znati nedostaje određena sintetizirajuća snaga, tj. cjelovita slika. Prema filozofu Damiru Barbariću zadaća sveučilišta je da oblikuje ljude »cjelovito i svestrano duhovno i duševno « tako da odgovaraju »cjelini onoga što jest « i da su s tom cjelinom »teoretski i praktički« usklađeni. ${ }^{8}$ Nadalje, na tragu Georga Wilhelma Friedricha Hegela, Barbarić percipira obrazovanje kao svojevrstan »rez« koji čovjek čini u svojem životu primjerice odlaskom na studij. Tako se obrazovanje shvaća kao »bolan, težak, dijelom i tragičan rastanak od bitno nevine, smirenim skladom s prirodnom cjelinom određene obiteljske egzistencije, prožete i vođene prvenstveno osjećajem i ljubavlju. U obrazovanju je sadržana bolna oštrina reza, odvajanja i razdvajanja; ono nije i ne može biti lišeno teškoće, napora, muke i boli oproštaja «. ${ }^{9}$

No, bez obzira na tu bol i žrtvu, taj rez je potreban čovjeku te veličina i snaga njegova duha mjere se upravo, rekli bismo, u tome koliko je čovjek spreman duboko u tom smislu »zarezati« u svoj život, tj. koliko je spreman otuđiti se od sebe, »od neposrednosti u kojoj se prirodno nalazi i u koju se ponovno vraća «. ${ }^{10}$ Drugim riječima, poanta je tog »reza « u stvari da znanje ne ostane samo na teoretskoj razini (iako je taj dio jako važan), nego i da taj »rez« dobije i svoje praktično očitovanje. U stvari, ključna je po Hegelu »cjelina jednoga i drugoga «. ${ }^{11}$ Mogli bismo reći da je u tome bit obrazovanja. Slično, citirajući Hans-Georga Gadamera, Barbarić primjećuje da je bit ljudskoga obrazovanja u tome da čovjek sebe učini »općenitim, duhovnim bićem «. To znači da onaj tko je prepušten partikularnim datostima zapravo nije obrazovan jer on ima problema s time da odvrati »pogled od sama sebe i usmjeri ga na nešto općenito «. ${ }^{12} \mathrm{U}$ najboljem slučaju, mogli bismo reći da je taj čovjek tek poluobrazovan.

Obrazovanje je primarno obrazovanje za znanost, i u tom smislu, navodeći Wilhelma von Humboldta, Barbarić ističe da se ključno obilježje znanja i obrazovanja nalazi u samoći i slobodi. Spoznaja, znanje i obrazovanje ne smiju biti

7 G. K. Chesterton, Pravovjerje, Split, 2015, str. 7.

8 D. Barbarić, Što je obrazovanje?, u: Isti (ur.), Čemu obrazovanje. Razmatranja o budućnosti sveučilišta, str. 151 (151-170).

9 Isto str. 154.

10 Isto str. 155.

11 Isto.

12 Isto str. 156. Autor se referira na djelo: H.-G. Gadamer, Warheit und Methode. Grundzüge einer philosophischen Hermeneutik, u: Isti, Gesammelte Werke, Bd.1., Tübingen, 1990, str. 18. 
sredstvo za nešto drugo i ono istinsko bavljenje znanošću moguće je samo »izvan okruženja životne nužde i potrebe« u odvojenosti od prakse i koristoljublja. ${ }^{13}$ Dakle, u jednoj, rekli bismo, smirenoj atmosferi gdje čovjek nije pod pritiskom različitih unutarnjih ili vanjskih čimbenika.

Tako ističe Barbarić da »sloboda znanosti nije samo sloboda od svega njoj izvanjskog, nego ujedno i sloboda od vlastite unutarnje upojedinjenosti i djelomičnosti. Istinska znanost bitno je cjelina, $\mathrm{i}$ to organska ${ }^{14}{ }^{14} \mathrm{O}$ tome je govorio još i Johann Gottlieb Fichte: »Mrtva je znanstvena građa dok god tu stoji pojedinačna i bez vidljive sveze sa cjelinom znanja $« .{ }^{15}$ Međutim, rekli bismo da je taj mir znanstvenika ujedno preduvjet, ali i cilj znanstvenoga istraživanja. Naime, svatko tko se bavi ili se bavio znanošću zna da znanstvenika prati i određeni pozitivan nemir u samom procesu učenja. Taj nemir lagano treperi u njegovu životu dok se približava cjelini bitka. On ne koči, nego je preduvjet postizanja mirnoga života u istini, onoga što bi trebao biti cilj obrazovanja za znanosti.

Nadalje znanost je »neprekidan proces učenja, predavanja, prisvajanja i novog proizvođenja živog znanja«, dakle, nije tek neki puki, nasumični zbroj gotovih spoznaja koje su samo skupljene ne gomilu. ${ }^{16}$ To je upravo ono što Humboldt govori kada ističe da znanost treba biti stvarana iz dubine duha i da se ne može sabirati tek ekstenzivnim prikupljanjem, tj. samo znanost koja »potječe od unutrašnjosti i može biti posađena u unutrašnjost preobražava karakter «. ${ }^{17}$ Svrha učenja je u tome da čovjeka pripremi za stvaranje. Barbarić spominje i Friedricha Wilhelma Josepha von Schellinga, koji tvrdi da čovjek tom »božanskom sposobnošću proizvodnje istinski jest čovjek, a bez nje samo tugaljivo, spretno spravljena mašina ${ }^{18}$

U tom kontekstu izuzetno je važna i uloga učitelja i učenika koji su zapravo prijatelji jer u svakom trenutku spremni su darovati cijeli jedan svijet (Nietzsche). ${ }^{19}$ Naravno, autoritativna distanca u tom prijateljstvu mora postojati, sve dok nije kočnica tog plemenitog procesa. U biti, rekli bismo da je potrebna poniznost učitelja prema cjelini znanja, ali i učenika prema toj istoj cjelini preko poštivanja učitelja koji prenosi učeniku dijelove te cjeline znanja svojim znanjem i konkretnim životom. Obrazovanje za znanosti u Humboldtovom smislu ne tiče se »samo

13 Isto str. 158.

14 Isto str. 160.

15 Isto. Autor se referira na djelo: J. G. Fichte, Deduzierter Plan einer zu Berlin zu errichtenden höheren Lehranstalt, u: Fichtes Gesammelte Werke hrsg. von J. H. Fichte, Berlin, 1845/1846, Bd. 8. str. 185.

16 Isto.

17 Isto. Autor se referira na djelo: W. von Humboldt, Gesammelte Schriften. Hrsg. von der königlichen Akademie der Wissenschaften. Abt. 2, Bd 10: Politische Denkschriften 1802-1810, hrsg. v.B. Gebhardt, Berlin, 1903, str. 397.

18 Isto str. 161. Autor se referira na djelo: F. W. J. Schelling, Vorlesungen über die Methode des akademischen Studiums, u: Isti, Sämmtliche Werke, hrsg. von K.F.A. Schelling, Bd. V., Sttutgart, 1856-1861, str. 241.

19 Isto. 
čovjekove teoretske i intelektualne sposobnosti ${ }^{20}$ Ono utječe na kompletan karakter osobe, njegovu intelektualnu ali i ćudorednu (moralnu) dimenziju. Ta cjelovita vizija obrazovanja koju donosi Humboldt, prema Barbariću, je »reakcija na isključivo instrumentalno, utilitarno i pragmatično shvaćanje znanja « koje je zavladalo Europom pojavom prosvjetiteljstva. ${ }^{21}$

No, nažalost današnji pristup obrazovanju uvelike se razlikuje od Humboldtovih zamisli, kao i filozofa tzv. njemačkog idealizma. Prema Barbariću, bitna odrednica te nove paradigme obrazovanja je ta da »na mjesto znanosti kao osamljene, individualne učenosti, dakle promišljanja cjeline bića i njegovih pojedinačnih okružja, stupa tehničko-institutski pogon timskoga rada na eksperimentalnoj konstrukciji područja znanstvene predmetnosti uopće, a na toj podlozi onda i samih pojedinačnih predmeta. «22 Danas umjesto znanstvenika imamo istraživače, tako da prema našemu autoru, koji vrlo iskreno i nehinjeno tvrdi, ništa nije ostalo od tog iz filozofije viđenog bitnog i istinskog obrazovanja, doduše jedino sofisti u tom kontekstu ne moraju strahovati za budućnost. ${ }^{23}$

Drugim riječima, danas smo izgubili iz vida bit obrazovanja u svim točkama na koje se referira Barbarić. Danas se ne obrazuje za život, nego za profesiju. Takvo »poluobrazovanje« generira deficit mislilaca i znanstvenika. Međutim, kako ističe Liessmann, »problem naše epohe nije poluobrazovanje, nego odsutnost svake normativne ideje obrazovanja, na kojoj bi se još dalo očitati nešto takvo poput poluobrazovanosti «. ${ }^{24}$ Prema tomu, očigledno je da treba promišljati o toj normativnoj ideji obrazovanja i na čemu je utemeljiti. Humboldtove ideje i ideje tzv. njemačkih idealista sasvim sigurno mogu nas nadahnuti u tom smislu, no problem je vrlo složen jer su se u međuvremenu dogodile dvije bitne transformacije unutar sustava obrazovanja.

\subsection{Izvrsnost $i$ kvaliteta kao glavni kriteriji obrazovanosti}

Prva transformacija je ona o kojoj je govorio Nietzsche. Druga je vrlo bliska prvoj, a odnosi se na ono što Bill Readings naziva transformacijom »sveučilišta kulture «u »sveučilište izvrsnosti «. ${ }^{25}$ To sveučilište izvrsnosti zapravo je sveučilište bez ideje jer ono traga za izvrsnošću, a ona je nulta kategorija koja je povezana s interesima globalnoga kapitala koji sve što »dotakne pretvara u sredstva vlastitoga rasta «. ${ }^{26}$ Dakle, ta izvrsnost mjeri se u odnosu prema »ekonomiji znanja «, a ona se uglavnom svodi na to da studenti budu prilagodljivi tržištu rada, da budu

20 Isto str. 162. Autor se referira na djelo: W. von Humboldt, Gesammelte Schriften. Hrsg. von der königlichen Akademie der Wissenschaften. Abt. 2, Bd 10: Politische Denkschriften 1802-1810, hrsg. v. B. Gebhardt, Berlin, 1903, str. 397.

21 Isto str. 163.

22 Isto str. 166.

23 Usp. Isto str. 170.

24 Usp. K. P. Liessmann, Posljednja zadaća našeg opstanka. O obrazovanju i njegovu deformiranju u razdoblju znanja, str. 114.

25 Usp. B. Readings, The University in Ruins, 1996. (preveo Š. Šokčević).

26 Isto str. 89. 
fleksibilni, mobilni za timski rad sposobni klonovi. U tom smislu i sveučilište se vrednuje u onoj mjeri koliko je doprinijelo rastu tržišta. Prema tomu vidimo da je kapital taj sveopći (univerzalni) segment kojemu takvo sveučilište teži. To usklađivanje s tržištem rada inače je omiljena mantra u društvenim i političkim krugovima te unutar medijskoga prostora gdje se mlade ljude već neposredno prije upisa na fakultet redovito usmjerava/indoktrinira da studiraju one smjerove koji će u budućnosti biti kompatibilni s tržištem rada. ${ }^{27}$

Na tim polazištima vrednuje se i »kvaliteta« pojedinog visokog učilišta. Naime, suvremeni sustav praćenja i osiguravanja kvalitete takvog (polu)obrazovanja rabi termine poput »kompetencija «, »ishod učenja $\aleph^{28}, »$ SWOT analiza «, »certificiranja «, tj. one pojmove koji su povezani s izobrazbom ili s procesima uspješne proizvodnje unutar tvrtki. Taj sustav je veliki birokratski potrošač energije koji, umjesto da unaprjeđuje, zapravo koči znanstveni rad. Tom tezom ne želimo diskreditirati sustav praćenja kvalitete na mnogim visokoškolskim ustanovama, jer smatramo da je kvalitetu obrazovanja potrebno pratiti i osiguravati. Samo želimo skrenuti pozornost da kvaliteta u smislu izobrazbe i proizvodnje te kvaliteta u smislu obrazovanja nisu jednake i da je u pozadini velika birokracija koja je često sama sebi svrhom.

Ako se želi osigurati kvaliteta na visokoškolskim ustanovama, onda se moraju primjenjivati jedni kriteriji za »ustanove obrazovanja«, a drugi za »ustanove životne nužde«. Povezanost obrazovnih ustanova i tržišta rada je naravno potrebna, ali smatramo da ne može tržište rada upravljati procesom obrazovanja i određivati njegovu kvalitetu. To je zapravo izdaja akademskoga duha, koji je u sebi, kao što smo vidjeli, ne-praktičan. Ako obrazovanje vodi prema nekomu praktičnomu ishodu, bio on ekonomski ili društveni, onda to, kao što smo vidjeli, nije istinsko slobodno obrazovanje i tako nešto ne može biti vizija i misija niti jednoga sveučilišta. Stoga, možda više nego ikada prije, potrebna nam je univerzalna vizija obrazovanja. No, jednako tako vidjeli smo da su nam potrebni i određeni normativni kriteriji, a za njihovu uspostavu očito je nužno i »nešto više $\ll$.

\subsection{Newmanova vizija obrazovanja}

Dilema koju smo otvorili - obrazovanje za život ili za karijeru, i nije neka nova dilema. Naime, još se u 19. stoljeću John Henry Newman (1801. — 1890.) bavio tom problematikom u svojem djelu The Idea of a University. ${ }^{29}$ Uzevši u obzir cjelinu njegovih rasprava o toj važnoj problematici, rekli bismo da je njegov

27 Usp. http://public.mzos.hr/Def (pristupljeno 14.05.2016.).

28 Tu se gotovo redovito koriste aktivni glagoli, što je krajnje neprilagođeno nastavi filozofije.

29 Tom djelu prethodila je serija Newmanovih rasprava o naravi sveučilišta. Godine 1859. on izdaje revidiranu verziju tih rasprava. U vremenu u kojem je obnašao rektorsku službu na novoosnovanom katoličkom sveučilištu u Dublinu (od 1854. do 1858.) održao je seriju od 10 prigodnih predavanja koje je objavio 1858. godine. Rasprave iz 1852./59. i 10 eseja objavljenih 1858. godine Newman je 1873. objedinio u djelo koje je danas poznato kao The Idea of a University. Suvremeno izdanje sastoji se od devet rasprava i četiri predavanja/eseja. 
stav takav da treba savjetovati studentima da izaberu profesiju, karijeru, ako to žele, ali moraju biti svjesni da na fakultetu nisu primarno da bi se trenirali za profesiju, nego da bi učili. To znanje koje stječu učenjem univerzalno je znanje koje nose čitav svoj život i primjenjuju ga u različitim životnim situacijama, tako da, iako se na prvu čini nepraktično, ono ima u daljnjoj perspektivi korisnu životnu primjenu. Naime, možda »kritička preciznost, elokventno izražavanje ne čine čovjeka bogatim, ne će spasiti dušu, ali to pomaže čovjeku da bude ono što je Bog u svojoj neograničenoj mudrosti htio da taj čovjek bude «, ističe Newman. ${ }^{30}$ Zato je Newmanova primarna nakana baveći se ovom problematikom bila pojasniti zašto je (katoličko) sveučilište važno.

Newman smatra da različita osobito sekularna sveučilišta koja nemaju teološko obrazovanje kao svoj sastavni segment zapravo nisu sveučilišta u pravom smislu te riječi jer ne poučavaju univerzalno znanje. ${ }^{31}$ Dakle, za njega je sveučilište mjesto poučavanja univerzalnog, općenitog znanja, koje ne može jednostrano isključiti ili marginalizirati jedno područje. Osim toga, cilj je sveučilišnoga obrazovanja stvoriti naviku promišljanja i kapacitete za društveno i građansko djelovanje, a ono ne može isključiti religijsku dimenziju. To obrazovanje treba biti slobodno, u smislu da je to obrazovanje za život, a ono može biti takvo jedino ako uzima u obzir cjelinu. ${ }^{32}$

Kao što smo vidjeli, danas kao i u Newmanovo vrijeme izgubljena je ta ideja jedinstva znanosti, koja bi trebala biti krucijalna u sveučilišnom obrazovanju. Sveučilišno obrazovanje dužno je poučavati kvantitativno sve znanosti, u duhu univerzalnosti, jer samo tako ono može voditi k istini i biti obrazovanje za život. Suvremeno sveučilište zanemarilo je obrazovanje za život uslijed utjecaja kapitala, ali jednako tako ono je marginaliziralo ulogu teologije kao forme znanja. Zbog toga, smatramo da mnoga suvremena sveučiliša možemo nazvati sveučilištima bez ideje, bez onoga što čini njihovu bit. U vremenu u kojem živimo sveučilište se ne bavi metafizičkim pitanjima, nego utilitarističkim shvaćanjima gdje znanje više nije slobodno.

30 J. H. Newman, The Idea of a University, London, 1947, str. 55 (preveo Š. Šokčević).

31 Usp. Isto str. 99.

32 O važnosti prisutnosti teologije na sveučilištu usp. J. H. Newman, The Idea of a University, New Haven, 1996, str. XIV-XV. (predgovor urednika F. M. Turnera). U tom kontekstu važno je napraviti i vrlo jasnu distinkciju između sveučilišnoga obrazovanja i djelovanja Crkve. Sveučilište je za Newmana institucija koja je u stanju oblikovati osobu koja ima široko znanje, kritičku inteligenciju, društvenu osjetljivost, koja ima i određenu moralnu čestitost, no sveučilište kao institucija nema zadatak da transformira grešna ljudska bića. Obrazovanje u filozofiji, književnosti i znanosti koje priprema studenta za život u grešnom, ljudskom društvu ne treba miješati sa stjecanjem moralnih krjeposti. Moralna, krjeposna osoba koja je razvila određene teologalne krjeposti zapravo to ostvaruje kroz učenje i praksu Crkve, a ne kroz proces sveučilišnoga obrazovanja. 


\section{Uloga teologije kao »forme slobodnoga zvanja«}

Ako usporedimo ideje von Humboldta i tzv. njemačkih idealista preko kojih smo došli do biti obrazovanja, onda možemo primijetiti da nema velikih razlika između njihovoga razumijevanja biti obrazovanja i Newmanove vizije. Međutim, ipak postoji jedna ključna razlika, koja po našem sudu Newmanovoj viziji daje prednost u daljnjim našim promišljanjima. Naime, još od prosvjetiteljstva, a osobito danas, vidimo da se jednu znanstvenu disciplinu osobito smatra suvišnom unutar sveučilišta. Riječ je, dakako, o teologiji. ${ }^{33}$ Nažalost, da bi sačuvala svoju kakvu-takvu poziciju unutar sveučilišta, teologija se nerijetko prepušta opasnim transformacijama (o kojima smo govorili) i prisiljena je biti ona koja priprema klerike i vjernike laike za njihove službe, profesije koji će djelovati na korist društva i države. Toj praksi marginalizacije $\mathrm{i}$ »profesionalizacije « teologije Newman se oštro protivi jer prema njegovu mišljenju sveučilište ne može postojati bez istinske, prave teologije. Smatramo da upravo to čini njegovu ideju posebnom i normativnom.

Njegova promišljanja o sveučilištu u The Idea of a University zapravo su odgovor na dvije tendencije aktualne u njegovo vrijeme, ali i danas. Prva je spomenuto gušenje tradicije teološkoga istraživanja u sklopu akademskoga, a druga je umanjivanje važnosti tzv. humanističkih znanosti. Kao i u Newmanovo vrijeme tako i danas argumente za izbacivanje teološkog iz akademskog diskursa možemo tražiti u tezama nekih filozofa koji smatraju da sofisticirani akademski pristup mora biti neovisan o teološkim tvrdnjama (Bernard Willliams). ${ }^{34} \mathrm{U}$ tom smislu razlozi za takvu marginalizaciju mogli bi se potražiti i u metodološkom ateizmu koji je prisutan danas, ali i u Newmanovo vrijeme. Međutim, to po našem mišljenju nisu ključni razlozi. Naime, ljudi koji su zaposleni unutar sveučilišta ne moraju biti nužno ateisti da bi odbacivali teološki diskurs na sveučilištu, čak štoviše veliki broj ljudi marginalizira teološki diskurs unutar sveučilišta, a nastavljaju pritom vjerovati u Boga i u tome ne vide ništa sporno.

\subsection{Razlozi marginalizacije teološkoga diskursa na sveučilištu}

Koji su onda glavni razlozi marginalizacije teološkoga diskursa? Iz analize Newmanovih promišljanja daju se iščitati tri ključna razloga. ${ }^{35}$ Prvo, ako gledamo na taj problem epistemološki, onda se možemo složiti s Newmanom da živimo u vremenu tzv. »strogog razuma«, koji je jedan od glavnih razloga te marginali-

33 Zapravo problem je marginalizacija cjelokupnog tzv. društveno-humanističkog i umjetničkog područja u odnosu na STEM područje prirodnih i tehničkih znanosti, što je primjerice osobito vidljivo u raspodjeli sredstava kojima se stimuliraju projekti i različite popularizacijske aktivnosti u znanosti.

34 Usp. B. Williams, Ethics and the Limits of Philosophy, Cambridge MA, 1985, str. 32-33 (preveo Š. Šokčević).

35 U tom kontekstu korisnu analizu donosi Daniel Cere. Usp. D. Cere, Newman, God and the Academy, u: Theological Studies, 55 (1994), str. 3-23 (preveo Š. Šokčević). 
zacije. ${ }^{36} \mathrm{~S}$ jedne strane taj strogo razumski aspekt zapravo filtrira naša uvjerenja na egzaktne standarde dokaza i vrlo je koristan. Naime, na taj način zaštićeni smo od opasnosti da prihvaćamo neke stvari kao istinite, a koje su zapravo lažne. Međutim, oduvijek je stavljanje naglaska na puki intelligo bilo problematično jer narav ljudskoga razuma je vrlo složena, neposredna i ne može se svesti tek na neku »usku, monolitnu znanost razumijevanja«, tj. domenu tzv. »strogoga razuma $\ll^{37}$

Problem takvoga »strogog razuma« najviše se očituje i u tome što je on često previše kritičan, a premalo kreativan. Jasan um, skrupulozne analize pomažu u tome da ne pogriješimo i one su nam svakako potrebne. Međutim, ti elementi »strogoga razuma« često ne mogu posijati sjeme istine. Drugim riječima »strogi razum «, da se tako slikovito izrazimo, uništava korov, ali ne može učiniti polje plodnim. Prakticirajući taj tip razuma, mi zapravo na neki način čekamo nekakav solidan dokaz i često uopće ne razumijevamo, nego samo ostajemo u čekanju. To je opasnost našega kritičkog razmišljanja jer time precjenjujemo kritički razum i ne otvaramo prostor za vjeru, a činjenica je da postoje mnoge istine koje možemo spoznati tek tada kad ih prigrlimo s vjerom i ljubavlju.

Osim dominacije tzv. »strogog razuma«, drugi razlog marginalizacije teologije unutar sveučilišta jesu prema Newmanu pijetistički i evangelički pokreti koji su umanjili važnost kognitivne dimenzije vjere. Ti subjektivistički pristupi daju prešutnu potporu repozicioniranju uloge teološkog i religijskog unutar akademskoga. ${ }^{38}$ I danas je taj utjecaj vidljiv i on je zapravo suprotan proces od prvoga razloga marginalizacije koji smo naveli.

Kao treći razlog Newman spominje deistički diskurs koji je dominantan unutar suvremenog sveučilišta. Riječ je o jednom šutljivom, podmuklom pristupu gdje se pod prizmom deističkoga nauka zapravo teologiju svodi samo na običan pogled na stvarnost koji je potpuno komenzurabilan s ostalim pogledima. Tako se i danas teologija promatra kao određena »glazura «, ukras onomu do čega su došle prirodne znanosti otkrivajući prirodne zakone koje je Bog odredio. Na taj način teologija ne doprinosi ozbiljnoj intelektualnoj raspravi. Takav pristup ima i opasne antropološke posljedice u smislu da se takvim shvaćanjem zapravo sve okreće prema subjektu, sebstvu, što u konačnici dovodi i do estetizacije morala, a predanje Bogu je zamijenjeno potrebom za samopoštovanjem. ${ }^{39}$

\subsection{Krug znanja}

Marginalizacija teologije, ali i drugih humanističkih znanosti, zapravo je krajnje apsurdna jer je sveučilište mjesto gdje se poučava univerzalno znanje. Pod univerzalnim znanjem mislimo na jedinstvo i integritet znanja. U odnosu

36 Usp. J. H. Newman, An Essay in Aid of a Grammar of Assent, Middletown, 2015, 123-136 (preveo Š. Šokčević).

37 Isto.

38 J. H. Newman, The Idea of a University, str. 20-21.

39 Usp. D. Cere, Newman, God and the Academy, str. 14-15. 
prema istini svaka znanstvena grana u određenoj mjeri je nedostatna, neadekvatna i zato bi različite discipline trebale služiti jedne drugima. S obzirom na to da je sveučilište mjesto univerzalnoga znanja (»sve-se-uči«), sve su znanstvene grane koje čine jedno sveučilište važne, pa tako i teologija ima važnu ulogu unutar sveučilišta.

Veliki je problem taj što se teologiju i teologe danas često ne percipira kao jednake sudionike $\mathrm{u}$ intelektualnim raspravama. Time se teologiji osporava uloga koju oduvijek ima, a to je da je ona »forma slobodnoga znanja «. ${ }^{40}$ To znači da se sveučilišna teologija treba promatrati kao forma znanja koja je cilj sama sebi, tj. nju nikako ne može determinirati korist. Kao rezultat bavljenja tim »slobodnim znanjem« javlja se tzv. »proširenje uma«, koje je zapravo izravna posljedica usporedbe i sistematizacije ideja. ${ }^{41} \mathrm{Na}$ taj način teologija, kao i svako »slobodno znanje «, u stvari oslobađa ljudsku osobu. Teologija se ne studira zbog utilitarnih ili profesionalnih razloga u smislu »uvježbavanja« za nekakvu službu jer se to oštro protivi poimanju teologije kao »forme slobodnoga znanja i zato prema Newmanu treba napraviti jasnu distinkciju između studija teologije i formacije $u$ bogoslovnim sjemeništima. Odmah treba reći da ta distinkcija ne znači da studij teologije i formacija u sjemeništu nisu komplementarni. Itekako jesu. No, Newman jasno ističe da sveučilište nije sjemenište ili samostan. ${ }^{42} \mathrm{U}$ sjemeništu se daje naglasak na primjenu teoloških učenja na život konkretnog studenta/bogoslova i osobito se pazi na moralni i religiozni razvoj budućih svećenika, dok, s druge strane, teologiju na sveučilištu mogu studirati ti isti budući svećenici, ali, kao što znamo, mogu ju studirati i ljudi koji ne će biti svećenici, pa čak i oni koji nikada ne će imati nikakvu službu unutar Crkve. Također, Newman »ne vidi da bi praktična primjena teologije u smislu vjerske ili moralne formacije morala biti primarni cilj studija teologije, već smatra da teologiju treba poučavati kao znanost «, kao »slobodno znanje«, kojoj je primarni cilj intelektualni razvoj osobe. Jedino tako ona može doći u dijalog s drugim znanostima na sveučilištu. ${ }^{43}$

Naravno, iako za Newmana primarna svrha teologije nije vjerska formacija, on bez sumnje smatra da je ona važan i integralan dio studija teologije, čak štovše smatra da se istinski krjeposna osoba može oblikovati tek kroz učenje, vjeru i praksu Rimokatoličke Crkve. ${ }^{44}$ Studij teologije svakako usmjerava prema izgradnji moralne i vjerske dimenzije kod osobe, pa u tom smislu teologija i formacija u sjemeništu se bitno prožimaju i nedovojivi su jedno od drugoga. To dakako uključuje i pretpostavku da bogoslovi studiraju teologiju ne na način

40 J. H. Newman, Idea of a University, str. 96. O važnosti uloge teologije na sveučilištu vidi: J. R. Connolly, Theology in a Catholic University: Newman's Significance for Today, u: Horizons 29. (2002), br. 2., str. 260-276.

41 Isto str. 205.

42 Isto

43 F. McGrath, The Consecration of Learning: Lectures on Newman's Idea of a University, New York, 1966, str. 173 (preveo Š. Šokčević).

44 Usp. J. H. Newman, Idea of a University, str. XV. (predgovor urednika F.M. Turnera, preveo Š. Šokčević). 
da im teologija bude usputna stanica koju će iskoristiti isključivo za dobivanje službe, nego ona koja će svojim »slobodnim znanjem « prožeti čitav njihov život i djelovanje te ih tako uz formaciju u sjemeništu oblikovati kao duhovno, moralno i intelektualno cjelovite osobe.

Osim toga, teologija mora biti u dijalogu s drugim znanostima na sveučilištu i, kao što ne smije biti podređena drugima znanostima, tako se ne smije predstavljati kao superiornija u odnosu na ostale znanosti, zato što sve znanosti prema Newmanu tvore jedan »krug znanja «. ${ }^{45}$ Stoga, teologija ne stoji u odnosu na druge znanosti kao primjerice »duša u odnosu na tijelo ${ }_{.}^{46}$ Ta pak tvrdnja vodi u tumačenje da su druge znanosti instrumenti ili privjesci teologiji. Drugim riječima, time bi učinili istu onu nepravdu koja se danas čini teologiji na mnogim sveučilištima. ${ }^{47}$

Unatoč tomu inzistiranju na jednakosti, u smislu da sve znanosti unutar sveučilišta tvore taj »krug znanja«, ipak činjenica je da Newman tvrdi »nešto više « za samu teologiju. ${ }^{48}$ On smatra da nas teologija uči najvišim istinama do kojih je čovjekov um sposoban doći. Teologija ima filozofsku strukturu, golem utjecaj, univerzalan karakter, nije stvar pomodarstva i ima svoje vječno mjesto $\mathrm{u}$ intelektualnom svijetu. Osim toga, teologija ima velik utjecaj na brojne grane znanja na način da ih ispravlja, upotpunjuje i sl. ${ }^{49}$ Teologija bitno pomaže drugim znanostima da bi one mogle doći do određenih istina do kojih samostalnim putem nikako ne bi mogle. Neki bi rekli da je teologija zbog toga »prva među jednakima«. Međutim, ta teza baš i ne stoji jer Newman ne govori o hijerarhiji, nego o »krugu«. Razumijevanje teologije kao prve u nizu pretpostavljalo bi hijerarhiju, a to se protivi Newmanovoj izvornoj ideji jer on smatra da je teologija posebna i njezina uloga nije u tome da bude nadređena u odnosu na druge znanosti, nego da im služi. Služi im tako što ih sintetizira, no ne zahvaljujući ljudskim metodama, nego time što ih upoznaje $\mathrm{s} »$ kraljevstvom znanja«, objavljenim istinama. Teologija služi time što transcendira druge znanosti, prožima ih u manjoj ili većoj mjeri bez da uništava njihovu autonomiju..$^{50}$

No, teologija mora pružiti i puno više od običnog usklađivanja teoloških kategorija sa sekularnim raspravama. Ona mora uključiti vjeru u Boga, koja je zahtjevna jer uzima u obzir ono što je čovjeku često najteže, a to je imperativ da umjesto samoga sebe transcendentalno drugoga i drugačijega stavi u središte svojega života. To je zapravo onaj istinski »rez« kojim čovjek umrtvljuje samo-

45 Isto str. 72.

46 Isto str. 398-399.

47 Usp. J. R. Connolly, Theology in a Catholic University: Newman's Significance for Today, str. 268 (preveo Š. Šokčević).

48 Usp. J. H. Newman, Idea of a University, str. 47.

49 Primjerice, etika, matematika, fizika, povijest ne mogu se do kraja razumjeti bez da su uzele u obzir što teologija kaže o tom području njihova istraživanja. Doduše, neke znanosti više ovise o teologiji, dok naravno ima i onih koje manje ovise. Primjerice kemiji i matematici teologija neće mnogo trebati, a ako neke teološke izvode ne uzmemo u obzir unutar politike, povijesti i sl., te znanstvene discipline mogu biti snažno zakinute za jedan aspekt znanja. Usp. Isto. str. 64.

50 Usp. J. R. Connolly, Theology in a Catholic University: Newman's Significance for Today, str. 269. 
dostatni egoizam i u poniznoj vjeri se otvara cjelini. $U$ tome je bit istinskoga obrazovanja, u promišljanju o dva samoevidentna bića: njemu samom i Bogu, ${ }^{51}$ koji je zapravo cjelina znanja. Na taj način, vidimo da istinski normativni kriterij valjanoga sveučilišnog obrazovanja treba tražiti u tome koliko je ono otvoreno teologiji i teološkomu. Bavljenje teološkim u sebi uključuje oblikovanje u skladu s cjelinom, jedinstvo teorijskog i praktičnog, te obrazovanje odvojeno od koristoljublja, što su, vidjeli smo, elementi kojima razlikujemo obrazovanje od poluobrazovanja.

\section{Zaključak}

Ljudski um izvorno želi stvoriti jedan koherentan pogled na stvarnost. Ako se marginalizira znanstvena grana koja u svojoj biti teži tomu, onda će njezino mjesto zauzeti neke druge povijesti, etike, filozofije itd. To najčešce dovodi do epistemološkog redukcionizma, koji urušava fundamentalna pitanja, sputava naš pogled na stvarnost i priječi hod prema istini. Smatramo da teologija ne treba biti kraljica unutar akademskog svijeta, nego je dovoljno da bude »sestra « u odnosu prema drugim znanostima. 52

Unutar sveučilišta važno je ostvariti interdisciplinarnost jer se na taj način stvara stabilna kognitivna osnova za znanstveno istraživanje. Različite znanosti zapravo su različiti, pojedinačni pogledi kojima »um promatra objekt $«{ }^{53} \mathrm{Ti}$ se pojedinačni pogledi provjeravaju, ispravljaju i sintetiziraju u sklopu jednog sveučilišnog foruma i jedino na taj način moguće je doći do objektivne istine.$^{54}$ Svojevrsno ograničenje koje se odnosi na ostale znanosti odnosi se i na teologiju. Teologija nije statična, deduktivna znanost i nema neko privilegirano mjesto u odnosu na druge znanosti unutar sveučilišta iako ima jedinstvenu narav.

Zbog razloga koje smo naveli teološki diskurs unutar sveučilišta danas je marginaliziran, međutim on je prisutan u mnogim zapadnim i ne-zapadnim kulturama. ${ }^{55}$ Prema tomu, on nije iščeznuo, ali akademski svijet (deistički) ne otvara taj diskurs, što je dakako velika pogrješka. Zanemarivanje tog diskursa unutar sveučilišta, usuđujemo se reći, jedan je od glavnih uzroka gotovo nepremostivog jaza između islama i sekularne kulture koji primjerice danas potresa Europu i koji može imati dalekosežne posljedice.

Dakle, na temelju analize koju smo poduzeli ovim radom, došli smo do dvije ključne smjernice za suvremeno obrazovanje. Prva je nužno oslobođenje od teškoga bremena birokracije, koja ljude na sveučilištu čini neslobodnima. Bi-

51 H. Graef posvetila je cijelu knjigu toj temi na kojoj Newman razvija svoju duhovnost. Usp. H. Graef, God and Myself. The Spirtuality of John Henry Newman, New York, 1968.

52 J.H. Newman, Idea of a University, str. 421.

53 Isto str. 34.

54 Usp. isto str. 35.

55 Pod zapadnim kulturama mislimo prije svega na sekulariziranu europsku i američku kulturu, pod ne-zapadnim mislimo prije svega na islamsku, muslimansku kulturu, gdje je to pitanje i dalje snažno zastupljeno. 
rokracija je potrebna, no ne i onda kada sama sebi postane svrha. Sustavi za praćenje i osiguravanje kvalitete sveučilišnoga obrazovanja i kvalifikacijski okviri također su potrebni, no ne ako će te okvire isključivo determinirati tržište rada i kapital kao takav. Kvalitetno obrazovana osoba je osoba cjelovita, slobodna znanja. Upravo takvo znanje treba biti glavni kriterij u procjeni kvalitete. Jedino tako obrazovana osoba ima prave kompetencije (znanje, vještine, samostalnost i odgovornost) za bilo koji posao i tržište rada. Stoga nam je danas potrebna univerzalna vizija obrazovanja koja mora uključivati sve discipline, pa tako i teologiju. ${ }^{56}$

Time dolazimo do druge smjernice za budućnost sveučilišta, a ona se odnosi na važnost rehabilitranja humanističkih znanosti, osobito teologije unutar akademskoga diskursa. Objektivno-normativni kriterij dobro utemeljene ideje sveučilišnoga obrazovanja upravo ovisi o tome u kolikoj mjeri takvo obrazovanje luči stvaralačke, kreativne ishode učenja, a to može tek ako nije zatvoreno u materijalno, tehničko, nego otvoreno prema onomu duhovnomu, teološkomu, tj. prema cjelini znanja. To naravno uključuje i potrebu da sama teologija bude više učenje o Bogu, a manje učenje o učenju o Bogu.

\section{Theology and the Idea of University Education}

\section{Šimo Šokčević*}

\section{Summary}

This article is a reflection on the crisis in modern education and attempts to offer guidelines for overcoming it. The first section analyzes the essence of education and makes evident that, in the context of modern trends, it is no longer viable today to speak of education, but rather of half-education. Half-education is particular in its approach for it does not encompass the integral vision of theoretical and practical knowledge which is the essence of education. By contrast, John Henry Newman spoke of the importance of the integral approach, and it is his vision of education that is the central theme of this paper. His idea involves the key role that theology plays in education as » a form of liberal knowledge", and this is the theme of the second section of the article. Here we explore the causes for the marginalization of theology at universities and conclude that it is in the discreditation of theology that the source of the contemporary crisis in education should be sought.

Key words: education, university, John Henry Newman, theology, »circle of knowledge«

56 To ne znači da u kurikulume prirodnih i tehničkih znanosti treba stavljati teološke traktate ili obrnuto, nego da treba raditi na suradnji, zajedničkim projektima, zajedničkim znanstvenim skupovima, znanstvenim radovima u kojima će ravnopravno participirati znanstvenici društvenog, humanističkog, umjetničkog i tzv. STEM područja, prirodnih i tehničkih znanosti.

* Šimo Šokčević, Ph.D., Assistant Professor, The Catholic Faculty of Theology in Đakovo. Adress: Petra Preradovića 17, p.p. 54., 31400 Đakovo, Croatia. E-mail: simo.sokcevic@djkbf.hr 